\section{Nigerian Studies}

Workers in Nigeria followed up these clues of filariasis and eosinophilia and defined the geographical distribution of the disease in relation to filariasis as seen in patients presenting in Ibadan. ${ }^{36}$ They discovered that patients with endomyocardial fibrosis rarely came from Ibadan itself or the savannah region to the north and west. They came predominantly from the rainforest area where infestation with Loa loa (a form of filariasis) was endemic. In a study using a filarial antigen for skin testing they found that patients with endomyocardial fibrosis reacted more frequently than the controls. They concluded that loiasis was the main form of filariasis associated with endomyocardial fibrosis but not the only form. The filarial hypothesis, which was fundamentally concerned with a sensitizing parasitic infestation, has not worn well in the light of conflicting geographical evidence and has been replaced by a more embracing concept.

As mentioned above, eosinophilia was frequently present in Europeans with endomyocardial fibrosis. Eosinophilia is also a manifestation of Löffler's endocarditis, a non-endemic, nontropical form of endomyocardial fibrosis which bears a striking macroscopic resemblance to tropical endemic endomyocardial fibrosis. Furthermore, in eosinophilic leukaemia some $40 \%$ of the reported cases have a heart lesion which is grossly indistinguishable from endomyocardial fibrosis. In other sporadic cases of non-tropical endomyocardial fibrosis eosinophilia has frequently been an associated finding. The unitarian hypothesis arising from these observations is that "the presence of an eosinophil leucocytosis, in a susceptible person, by some unknown mechanism, causes endomyocardial damage." 37 Endomyocardial fibrosis, Löffler's endocarditis, the endomyocardial fibrosis of eosinophilic leukaemia, and other endomyocardial conditions with eosinophilia are thus all variants of the same cardiopathy, varying only in the acuteness of presentation and the severity of the damage. ${ }^{37} 38$
It is of some interest to the hypothesis of the pathogenic eosinophil that the tropical condition associated with the most severe degree of eosinophilia is not known to produce appreciable cardiac damage. ${ }^{39} 40$ I refer to tropical eosinophilia, a condition of high eosinophilia associated with pulmonary symptoms and characteristic radiographic changes, almost certainly produced by a non-human filarial infestation. Tropical eosinophilia is commonly seen in India, Pakistan, and Ceylon and it occurs very rarely in tropical Africa, where endomyocardial fibrosis is endemic.

I intend no pun when I say that eosinophilia in endomyocardial fibrosis is a red herring. It is the underlying immunological status of the individual which is probably of major importance, and this may or may not be associated with an eosinophilia. A study of the immunoglobulin and tissue autoantibody patterns in non-tropical, non-endemic cases of endomyocardial fibrosis would be of considerable interest.

\section{Conclusion}

I do not want to convince you of any particular hypothesis concerning endomyocardial fibrosis. What does seem important in the story is not only an infection but a susceptible host. I would like to think that when the final chapters in the endomyocardial saga come to be written we may, in the process of studying this disease, have made a contribution to the understanding of individual susceptibility in other diseases, including rheumatic fever. We have the unique opportunity of applying the scientific methods of the 1970s to disease situations encountered in Great Britain in the previous century and present in the tropical world of today.

Part III of these lectures will appear in next week's issue. A list of references will be given in part IV, to be published in our issue of 7 October.

\title{
Reactions to Drugs
}

\section{Evaluation of Spontaneous Reports of Adverse Reactions to Drugs}

\author{
WILLIAM H. W. INMAN, DAVID A. PRICE EVANS
}

British Medical fournal, 1972, 3, 746-747

\section{Summary}

An adverse drug-reaction monitoring system based on spontaneous reporting to a central register of adverse reactions has been in operation for eight years. As a test of the validity of the reports and of the probability of causal relationship between drug and reaction a random sample of 82 cases were followed up in detail. The sample included 17 deaths, 26 serious reactions, and 39 reactions of moderate or only minor severity. Altogether $78 \%$ of the reactions were considered to be "probably" drug

Committee on Safety of Medicines, London E.C.2

WILLIAM H. W. INMAN, M.B., M.R.C.P., Senior Medical Officer

Nuffield Unit of Medical Genetics, Department of Medicine, University of Liverpool

DAVID A. PRICE EVANS, M.D., F.R.C.P., Professor of Medicine related and $13 \%$ "possibly" drug related. It is concluded that the reports are of value in the detection and evaluation of drug safety.

\section{Introduction}

In 1964 the Committee on Safety of Drugs* established an adverse reactions reporting system managed by its Subcommittee on Adverse Reactions. Doctors, dentists, and, later, coroners were invited to submit summarized reports of suspicious events after the use of drugs to a central Register of Adverse Reactions. Since then between 3,000 and 5,000 reports have been received each year, about three-quarters of these on a business reply card (the "yellow card"). About half of the reports are from general practitioners and the remainder are from hospitals, of Medicines. 
dental surgeons, family planning clinics, coroners, or the pharmaceutical industry. The reports have been of excellent quality, and a high proportion of them describe serious or even fatal events, but they are believed to represent only a very small portion of the number of adverse reactions that actually occur.

Doubts have frequently been expressed about the validity of anecdotal accounts of suspected adverse reactions. It is not possible to pursue each report exhaustively, but the committee have built up a team of medically-qualified investigators who conduct case work on a part-time basis. These now number about 80 , and all parts of the country can be reached by one or other member of the team, although at the time of this study only about 30 officers were available.

To obtain a clearer view of the validity of the case material on which the reports are based and of the probability of causal relationship between drug and reaction an attempt has been made to obtain more details by follow-up of a sample of the reports selected at random. In this way it is hoped that the results may be generalized to the whole input to the adverse reactions register.

\section{Methods}

Each report is allocated a serial number on receipt, and by using a table of random numbers 100 reports were selected from 1,000 consecutive reports received between April and July 1971 . Although the annual rate of reporting has varied little from year to year it should not be assumed that this sample is truly representative of all the reports the committee has received. Where possible arrangements were made by a personal letter to follow up the report by an interview with one of the committee's field workers. Where this was not possible, generally because a field worker was not available in the area from which the report had originated, follow-up was completed by correspondence. During the course of each inquiry information was obtained about the patient's past and recent history. This included details of the use of any drugs not mentioned in the original report, the indications for treatment, and an account of any appreciable alteration of the patient's condition subsequent to the report. A standard questionnaire was supplemented where necessary by additional documents such as copies of necropsy reports or hospital discharge summaries.

Causal relationship between the suspected drug and the reaction was rated as "probable" when it was certain or nearly certain that the drug had been responsible for the reaction. Factors which operated in favour of this decision included a history of rechallenge reactions, a strong temporal relation between administration and reaction, evidence of a doseresponse relation, evidence of a localized reaction-for example, at an injection site-and known physiological or pathological responses which are reproducible in human or animal experiments.

Reactions were rated "possible" when it was less than certain that the drug was responsible or when reasonable alternative hypotheses might be advanced. This category included events which are sometimes drug-related but which also have a spontaneous or idiopathic incidence. Causality was assessed as "unlikely" if a better explanation for the adverse reaction could be found. This included a small number of reports in which suspicious events were thought after follow-up to be unrelated to the use of the drug. In one case, for example, a consultant dermatologist suggested that a "drug rash" was due to insect bites. The reports were assessed in this way both before and after follow-up so that this procedure could be evaluated.

\section{Results}

Follow-up was abandoned in 14 cases. In four reports the doctor had failed to give an address or a legible signature. In one case no details could be obtained about a man found dead in bed and the cause of death was not established. In the remaining nine it was not possible to contact or interview the reporting doctor within six months of receiving his report. In addition there were four reports of pregnancy suspected to be due to "method failure" among women using oral contraceptives. These are not considered further in this paper. The remaining 82 reports were followed up; 37 were from general practitioners, 25 from hospitals, 10 were summaries of death certificates supplied by the Registrar General, and the remaining 10 were from various sources (coroner 3, Family Planning Association clinics 2, pharmaceutical industry 2 , medical officers of health 2 , and a dental surgeon 1). Fifty-seven of the reports were followed up by personal interview with a field worker and 25 by correspondence. Altogether 26 of the 37 reports from general practitioners $\left(70^{\circ}{ }_{0}\right)$ and 31 of 45 from other sources $\left(69^{\circ}{ }_{0}^{\circ}\right)$ were followed up by interview.

Seventeen of the reports described fatal events, and 10 of these reached the committee as summaries of death certificates, 26 described serious reactions, most of which were potentially life-threatening conditions, 17 moderately severe, and the remaining 22 minor or trivial reactions (Table I). In 14 cases the drug was considered to be a probable cause of death, while in the remaining three it was considered to be only a possible cause (Table II). In only two of the 17 reports was the assessment of causal relationship modified as a result of follow-up.

\begin{tabular}{|c|c|c|c|c|c|}
\hline \multirow{2}{*}{ Source } & \multicolumn{4}{|c|}{ Severity of Reaction } & \multirow{2}{*}{ Total } \\
\hline & Fatal & Serious & Moderate & Minor & \\
\hline $\begin{array}{l}\text { General practitioner } \\
\text { Hospital } \ldots \\
\text { Registrar General } \\
\text { Others } \quad . .\end{array}$ & $\begin{array}{r}1 \\
2 \\
10 \\
4\end{array}$ & $\frac{10}{3}$ & $\begin{array}{r}12 \\
\frac{3}{2}\end{array}$ & $\begin{array}{r}14 \\
\frac{7}{1}\end{array}$ & $\begin{array}{l}37 \\
25 \\
10 \\
10\end{array}$ \\
\hline Total & 17 & 26 & 17 & 22 & 82 \\
\hline
\end{tabular}

TABLE II-Suspected Drug in 17 Reports of Fatal Reactions with Number of TABLE $11-S u s p e c t e d$ Drug in 17 Reports of Fatal Reactions with Number
Concurrently Administered Drugs and Assessment of Causal Relationship

\begin{tabular}{|c|c|c|c|c|}
\hline $\begin{array}{l}\text { Series } \\
\text { No. }\end{array}$ & Cause of Death & Suspected Drug & $\begin{array}{l}\text { No. of } \\
\text { Other } \\
\text { Drugs }\end{array}$ & $\begin{array}{l}\text { Assessment } \\
\text { of Causality }\end{array}$ \\
\hline $\begin{array}{r}1 \\
2 \\
3 \\
4 \\
5 \\
6 \\
7 \\
8 \\
9 \\
10 \\
11 \\
12 \\
13 \\
14 \\
15 \\
16 \\
17\end{array}$ & $\begin{array}{l}\text { Agranulocytosis } \\
\text { Aplastic anaemia } \\
\text { Aplastic anaemia } \\
\text { Aplastic anaemia } \\
\text { Pancytopenia } \\
\text { Subdural haematoma } \\
\text { Pulmonary embolism } \\
\text { Cerebral thrombosis } \\
\text { Pneumonia } \\
\text { Haematemesis } \\
\text { Haematemesis } \\
\text { Haematemesis } \\
\text { Haematemesis } \\
\text { Hyperthermic coma } \\
\text { Unexplained death } \\
\text { Moderate overdose } \\
\text { Moderate overdose }\end{array}$ & $\begin{array}{l}\text { Phenylbutazone } \\
\text { Chloramphenicol } \\
\text { Phenylbutazone } \\
\text { Sodium aurothiomalate } \\
\text { Thiotepa } \\
\text { Warfarin } \\
\text { Oral contraceptive } \\
\text { Oral contraceptive } \\
\text { Prednisone } \\
\text { Acetylsalicylic acid } \\
\text { Heparin } \\
\text { Phenindione } \\
\text { Prednisolone } \\
\text { Trifluoperazine } \\
\text { Chlorpromazine } \\
\text { Nitrazepam } \\
\text { Orphenadrine }\end{array}$ & $\begin{array}{l}\frac{-}{7} \\
2 \\
\frac{2}{7} \\
\frac{1}{9} \\
\frac{1}{1} \\
7 \\
1 \\
6 \\
1 \\
2\end{array}$ & $\begin{array}{l}\text { Probable } \\
\text { Probable } \\
\text { Probable } \\
\text { Probable } \\
\text { Probable } \\
\text { Probable } \\
\text { Probable } \\
\text { Probable } \\
\text { Probable } \\
\text { Probable } \\
\text { Probable } \\
\text { Probable } \\
\text { Probable } \\
\text { Probable } \\
\text { Possible } \\
\text { Possible* } \\
\text { Possible* }\end{array}$ \\
\hline
\end{tabular}

* Assessed as probable before follow-up.

These were deaths attributed to comparatively small overdoses of drugs which were normally regarded as safe. A similar assessment of 26 serious (non-fatal) reactions is shown in Table III. In eight of these follow-up led to modification of the original assessment of causal relationship.

The results of follow-up of the remaining 39 reports of moderate or minor reactions are summarized in Tables IV and $V$. Nearly half of these were rashes and one or other of 30 different types of drug was regarded as the suspect agent.

Two cases illustrate the value of follow-up.

Case 1.-A Certificate related to the death of a woman aged 38 attributed to aplastic anaemia due to chloramphenicol administered in 1959. The case was followed up by correspondence since no local field worker was available. The patient had received a five-day course of chloramphenicol in 1959 for pharyngitis and had developed aplastic anaemia with thrombocytopenia. She was kept alive for 11 years 
TABLE III-Suspected Drug in 26 Reports of Serious Reactions with Number of Concurrently Administered Drugs and Assessment of Causal Relationship made after Follow-up

\begin{tabular}{|c|c|c|c|c|}
\hline $\begin{array}{c}\text { Series } \\
\text { No. }\end{array}$ & Reaction & Suspected Drug & $\begin{array}{l}\text { No. of } \\
\text { Other } \\
\text { Drugs }\end{array}$ & $\begin{array}{l}\text { Assessment } \\
\text { of Causality }\end{array}$ \\
\hline $\begin{array}{l}18 \\
19 \\
20 \\
21 \\
22 \\
23 \\
24 \\
25 \\
26 \\
27 \\
28 \\
29 \\
30 \\
31 \\
32 \\
33 \\
34 \\
35 \\
36 \\
37 \\
38 \\
39 \\
40 \\
41 \\
42 \\
43\end{array}$ & $\begin{array}{l}\text { Aplastic anaemia } \\
\text { Macrocytic anaemia } \\
\text { Macrocytic anaemia } \\
\text { Macrocytic anaemia } \\
\text { Folic acid deficiency } \\
\text { Pulmonary embolism } \\
\text { Coronary thrombosis } \\
\text { Cerebral thrombosis } \\
\text { Leg vein thrombosis } \\
\text { Leg vein thrombosis } \\
\text { Leg vein thrombosis } \\
\text { Raynaud's syndrome } \\
\text { Postural hypotension } \\
\text { Haematemesis } \\
\text { Haematemesis } \\
\text { Anaphylactic shock } \\
\text { Anaphylactic shock } \\
\text { Jaundice } \\
\text { Jaundice } \\
\text { Jaundice } \\
\text { Respiratory depression } \\
\text { Convulsion } \\
\text { Addiction } \\
\text { Adrenal suppression } \\
\text { Exfoliative dermatitis } \\
\text { Drug potentiation }\end{array}$ & $\begin{array}{l}\text { Chlorpromazine } \\
\text { Sulphamethoxazole } \\
\text { Sulphamethoxazole } \\
\text { Tolbutamide } \\
\text { Oral contraceptive } \\
\text { Oral contraceptive } \\
\text { Oral contraceptive } \\
\text { Oral contraceptive } \\
\text { Oral contraceptive } \\
\text { Oral contraceptive } \\
\text { Oral contraceptive } \\
\text { Stilboestrol } \\
\text { Practolol } \\
\text { Aspirin } \\
\text { Ibuprofen } \\
\text { Ethanolamine } \\
\text { Nalidixic Acid } \\
\text { Glibenclamide } \\
\text { Imipramine } \\
\text { Rifampicin } \\
\text { Diamorphine } \\
\text { Measles vaccine } \\
\text { Ergotamine } \\
\text { Clotrimazole } \\
\text { Clofibrate } \\
\text { Pentazocine }\end{array}$ & $\begin{array}{l}2 \\
1 \\
1 \\
\frac{2}{7} \\
\frac{2}{Z} \\
= \\
\frac{7}{3} \\
\frac{3}{7} \\
\frac{3}{1} \\
2 \\
\frac{4}{4} \\
4 \\
5 \\
1\end{array}$ & $\begin{array}{l}\text { Probable } \\
\text { Probable* } \\
\text { Probable* } \\
\text { Possible } \\
\text { Unlikely* } \\
\text { Probable } \\
\text { Possible } \\
\text { Probable } \\
\text { Probable } \\
\text { Probable } \\
\text { Probable } \\
\text { Unlikely* } \\
\text { Probable } \\
\text { Probable } \\
\text { Possible } \\
\text { Probable } \\
\text { Probable } \\
\text { Probable } \\
\text { Probable } \\
\text { Probable } \\
\text { Probable } \\
\text { Possible† } \\
\text { Unlikely } \\
\text { Unlikely* } \\
\text { Probable } \\
\text { Unlikely* }\end{array}$ \\
\hline
\end{tabular}

* Assessed as possible before follow-up.

† Assessed as probable before follow-up.

TABLE IV-Details of Minor or Moderately Severe Reactions and Suspected Drigs in 39 Reports

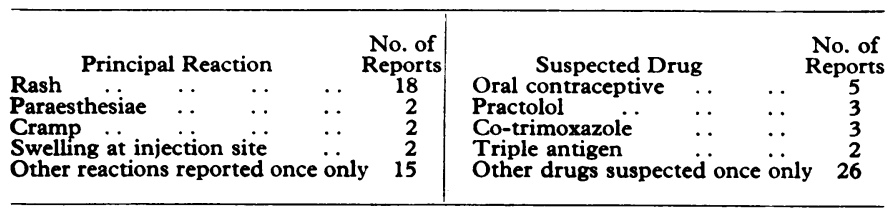

TABLE V-Assessment of Minor or Moderately Severe Reactions Before and After Follow-up in 39 Reports

\begin{tabular}{c|c|c}
\hline \multicolumn{2}{c|}{ Assessment } & \multirow{2}{*}{ No. of Reports } \\
\cline { 1 - 2 } Before Follow-up & After Follow-up & \\
\hline Probable & Unchanged & 33 \\
Probable & Possible & 2 \\
Probable & Unlikely & 1 \\
Possible & Unchanged & 2 \\
Possible & Unlikely & 1 \\
\hline
\end{tabular}

with the help of frequent blood transfusions, steroids, and antibiotics. There were some periods of remission, including one of nearly 12 months in 1968. She finally succumbed to pseudomonas septicaemia in October 1970.

Case 2.-A hospital report of thrombocytopenia and aplastic anaemia affecting a 64-year-old man who had been treated with phenylbutazone was followed up by interview with the reporting doctor. It was established that the patient had died from intracranial haemorrhage resulting from aplastic anaemia after treatment with phenylbutazone. A short course of phenylbutazone had been given to treat a small patch of superficial venous thrombosis of the leg. Two weeks after completing this course he developed purpura and was found to have a low platelet count and complete agranulocytosis. He succumbed to staphyloccal septicaemia on the 48th day after the first dose of phenylbutazone. It was recorded that he had received treatment with phenylbutazone nine years previously without adverse reaction.

In the first case a possible transcription error (1969 for 1959) was excluded and it was established that as a result of skilful care the patient had survived for 11 years with aplastic anaemia induced by chloramphenicol. Chloramphenicol had been given at a time when its unfortunate tendency to damage the bone marrow was not widely recognized. In the second case followup established that the patient had died (he was alive when the report was submitted) and that his illness was due to a second exposure to phenylbutazone.

\section{Discussion and Conclusions}

The British system for early detection of drug hazards and some of its limitations were reviewed by Professor Witts, ${ }^{1}$ the first chairman of the Subcommittee on Adverse Reactions. Several examples of potentially dangerous situations necessitating the publication of a warning or withdrawal of a drug were given by Sir Richard Doll, ${ }^{2}$ the present chairman. Action may sometimes be necessary on the basis of the few reports that are available to the committee and may have to be taken with the knowledge that reporting might have been incomplete or, on the other hand, that it might have been selective and led to a false conclusion that a risk existed where none was present. During their investigation of deaths from thromboembolism Inman and Vessey $^{3}$ found that only $15 \%$ of deaths among a group of women using oral contraceptives were reported spontaneously to the committee. Inman ${ }^{4}$ showed that only six reports of deaths of asthmatics as a suspected effect of overuse of pressurized aerosol bronchodilators were received during the first two full years of operation of the reporting system (1965 and 1966), while it was estimated that more than 1,700 deaths during this period might have been attributed to the use of these drugs. Under-reporting may be even more of a problem for non-fatal events, and the two examples point to a need for a general increase in reporting if new hazards are to be detected early.

Since all the reports that are registered cannot be followed up it is important to assess their overall value as a basis for further investigation. In this study the use of a sample of the reports selected at random, which included some trivial reactions of a type that would not normally call for individual follow-up, was thought to offer the best prospects for assessing the overall validity of the whole collection of data.

The present sample included an unusually large proportion of fatal reactions ( 17 deaths in 82 reports). During the eight years the committee have been receiving reports about $11 \%$ have been of fatal reactions. At the time the sample was taken in 1971 the "yellow card" reporting was at a relatively low level. Since the input of data to the committee derived from death certification was unchanged the proportion of fatal notifications was relatively larger than during the earlier years. During the whole year the proportion of fatal reactions was $13 \%$.

Fourteen of the 17 fatal reactions were considered to be probably related and the remainder possibly related to the use of the suspect drug. Seventeen of 26 serious reactions were rated "probable," four "possible," and five "unlikely." Among the moderately severe or minor reactions the proportion of probables was even higher. Out of 39 reports 33 were placed in this category.

In this investigation cases were chosen for follow-up at random. Normally only selected cases would be investigated in detail by the committee's field workers, most often because a group of similar reports had suggested that a new and previously.

TABLF VI-Modification of Assessment of Causal Relationship and Addition of Useful Data resulting from Follow-up

\begin{tabular}{|c|c|c|c|c|c|c|}
\hline \multirow{2}{*}{\multicolumn{2}{|c|}{. }} & \multirow{2}{*}{$\begin{array}{c}\text { No. } \\
\text { of } \\
\text { Reports }\end{array}$} & \multicolumn{2}{|c|}{$\begin{array}{l}\text { Assessment } \\
\text { Modified by } \\
\text { Follow-up }\end{array}$} & \multicolumn{2}{|c|}{$\begin{array}{c}\text { Useful Data } \\
\text { Added by } \\
\text { Follow-up }\end{array}$} \\
\hline & & & Yes & No & Yes & No \\
\hline $\begin{array}{l}\text { Fatal or serious } \\
\text { reactions }\end{array}$ & $\left\{\begin{array}{l}\text { G.P. } \\
\text { Other }\end{array}\right.$ & $\begin{array}{l}10 \\
22\end{array}$ & $\begin{array}{c}\text { Follo } \\
2 \\
4\end{array}$ & $\begin{array}{r}8 \text { by } \\
18\end{array}$ & $\begin{array}{r}\text { view } \\
8 \\
19\end{array}$ & $\begin{array}{l}2 \\
3\end{array}$ \\
\hline \multirow[t]{2}{*}{$\begin{array}{l}\text { Moderate or } \\
\text { minor reactions }\end{array}$} & $\left\{\begin{array}{l}\text { G.P. } \\
\text { Other } . .\end{array}\right.$ & $\begin{array}{r}16 \\
9\end{array}$ & $\begin{array}{l}1 \\
1\end{array}$ & $\begin{array}{r}15 \\
8\end{array}$ & $\begin{array}{l}7 \\
7\end{array}$ & $\begin{array}{l}9 \\
2\end{array}$ \\
\hline & Total & 57 & 8 & 49 & 41 & 16 \\
\hline $\begin{array}{l}\text { Fatal or serious } \\
\text { reactions }\end{array}$ & $\left\{\begin{array}{l}\text { G.P. } \\
\text { Other } . .\end{array}\right.$ & $\begin{array}{r}1 \\
10\end{array}$ & $\frac{\text { Follow- }}{4}$ & $\begin{array}{c}C \text { Cor } \\
1 \\
6\end{array}$ & $\frac{\text { ondenc }}{9}$ & 1 \\
\hline $\begin{array}{l}\text { Moderate or } \\
\text { minor reactions }\end{array}$ & $\left\{\begin{array}{l}\text { G.P. } \\
\text { Other } . .\end{array}\right.$ & $\begin{array}{r}10 \\
4\end{array}$ & $\underline{2}$ & $\begin{array}{l}8 \\
4\end{array}$ & $\underline{6}$ & $\begin{array}{l}4 \\
4\end{array}$ \\
\hline & Total & 25 & 6 & 19 & 15 & 10 \\
\hline & Grand Total & 82 & 14 & 68 & 56 & 26 \\
\hline
\end{tabular}


unrecognized hazard might exist or because the reaction appeared to be of an unusual or even bizarre type or because the subcommittee was seeking to establish that a certain clinical sequence was, in fact, due to a particular drug. In such cases the probability that the reported events are drug-related may be either more or less than was found in this sample.

As might be expected the proportion of serious or fatal reactions was higher in hospital reports $(60 \%)$ than in those sent by general practitioners $(32 \%)$. The preliminary assessment of causal relationship was modified as a result of follow-up in 14 cases (see Table VI). "Probable" assessments before follow-up were changed to "possible" in five cases and "unlikely" in one. "Possible" assessments were changed to "probable" in two cases and "unlikely" in six. It is the usual practice of the committee to record all reports in the register of adverse reactions so that no event, however improbable it may be that a drug has caused it, will be overlooked permanently. This practice may have influenced the assessment of some of the more doubtful cases before follow-up, and it is likely that this accounted for the fact that six of the seven cases assessed as "unlikely" after follow-up were rated "possible" initially. Useful information was obtained in 41 out of 57 interviews $(72 \%)$ compared with 15 out of 25 investigations completed by correspondence $(60 \%)$. But the advantages of interview were even more apparent in both the quality and quantity of the additional data obtained than these proportions suggest.

The following general conclusions can be reached as a result of this analysis. (1) Valuable information can be obtained by follow-up whether by correspondence or interview, but the second approach is more rewarding and is preferable if deductions are to be made which may affect the future use of a drug. (2) Causal relationship does not appear to be related to the severity of the reported reactions. (3) Of the 82 reactions 64 $(78 \%)$ were considered to be probably drug related, $11(13 \%)$ possibly related, and only $7(9 \%)$ unrelated to the use of the suspect drug. Since the sample is believed to be fairly representative of the total input of reports, and because a high proportion of drug-related reactions were confirmed by follow-up, many of the reports to the committee are likely to be true examples of drug reactions. (4) The present system of reporting is valuable and should be encouraged because it forms the basis for more detailed investigations which may yield new knowledge.

We wish to thank Professor Eric Scowen, Sir Richard Doll, and Dr. David Mansel-Jones for their helpful comments, and the Committee on Safety of Medicines for permission to make use of these data.

Requests for reprints should be addressed to Dr. W. H. W. Inman, Committee on Safety of Medicines, 33/37A Finsbury Square, London EC2A 1PP.

\section{References}

1 Witts, L. J., British Medical fournal, 1965, 2, 1081.

2 Doll, R., British Medical fournal, 1969, 2, 69.

3 Inman, W. H. W., and Vessey, M. P., British Medical fournal, 1968, 2, 193.

4 Inman, W. H. W., British Medical Bulletin, 1970, 26, 248.

\title{
European Counterparts
}

\section{Variations in Pharmaceutical and Medical Practice in Europe}

\author{
SIR DERRICK DUNLOP, R. S. INCH
}

\section{British Medical fournal, 1972, 3, 749-752}

The statement that medicine is international and knows no frontiers has become almost a platitude. It is true, of course, that throughout the world our profession has roughly the same ideals and speaks to some extent the same clinical and scientific lingua franca. The diagnosis and treatment of most diseases, too, such as appendicitis, pneumonia, and rheumatism are similar in different countries and therapeutic success depends on the skill of the physician or surgeon and the resistance of the patient. Nevertheless, the advent of more rapid communications and the tendency to form wider groupings like the Common Market have made it clear that it is a gross oversimplification to assume that the practice of medicine is at all homogeneous, even in the western world. There is, however, a universal search for higher standards and there are great advantages in submitting our long established national conventions, institutions, and attitudes for criticism by our colleagues in other countries. It is also salutary for us in the United Kingdom to remember that in Europe fairly comprehensive health services exist in various ways with good hospital facilities which in some inst-

Sterling-Winthrop Group Ltd., Surrey

SIR DERRICK DUNLOP, M.D., F.R.C.P., Director

R. S. INCH, M.D. Deputy Chairman ances are superior to our own. In this paper an attempt has been made to portray some of the odd divergencies which occur in different parts of Europe in pharmaceutical and medical practice.

\section{Pharmaceutical Industry}

The multitude of controls imposed on the pharmaceutical industry varies enormously in different countries, and even within the Common Market there are still many regulations preventing the free movement of medicines from one country to another. Thus pharmaceutical products manufactured in Britain or France can be imported freely into Germany, Switzerland, and the Scandinavian countries, provided they are manufactured so as to comply with certain specifications, but not into Belgium, where all products must be packed under the supervisory control of a Belgian pharmacist. Although there is close co-operation in Benelux countries it is easier for Holland to import Belgian-packed medicines than for Belgium to import Dutch. France has such stringent rules that it is virtually impossible to import medicines except on a small scale by a Government agency. It is extremely difficult to find a colouring agent which will be at once acceptable in the U.S., U.K., and continental countries. There are wide variations in different 